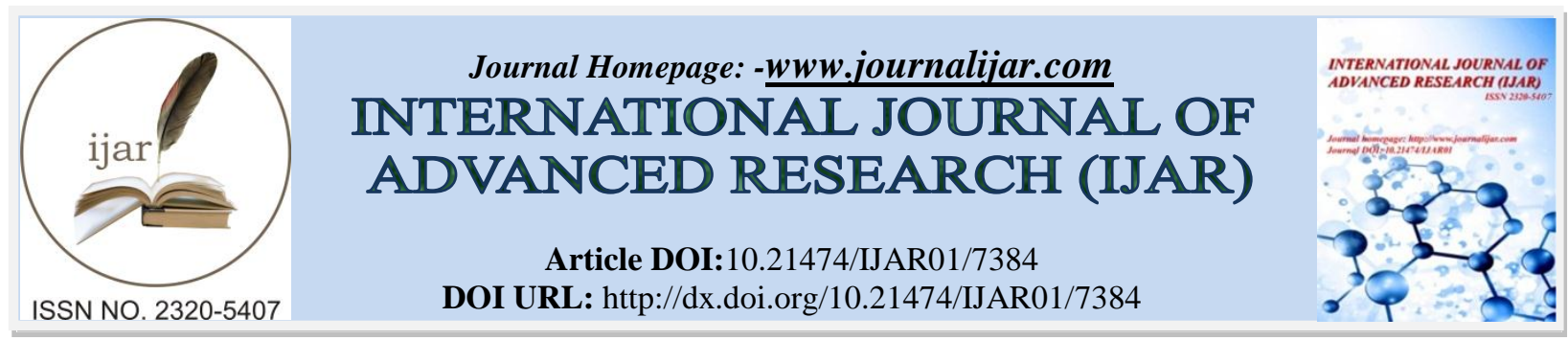

RESEARCH ARTICLE

\title{
OCCUPATIONAL HEALTH HAZARDS AND THEIR CAUSES AMONG WOMEN IN INDIAN AGRICULTURE.
}

\author{
Neha Kanojia ${ }^{1}$ and Smita Tripathi ${ }^{2}$. \\ 1. Post Doctoral Fellow, College of Home Science. \\ 2. C.S. Azad University of Agriculture and Technology, Kanpur.
}

\section{Manuscript Info}

Manuscript History

Received: 10 May 2018

Final Accepted: 12 June 2018

Published: July 2018

Keywords:-

Occupational, Hazards, Causes, Women, Agriculture.

\begin{abstract}
Women's contribution to agriculture, whether it is in subsistence farming or commercial agriculture, when measured in number of tasks performed and time spent, is greater than men. The proportion of women in agricultural production and postharvest activities ranges from 20 to $70 \%$ and their involvement is increasing in many developing countries, particularly with the development of export-oriented irrigated farming, which is associated with a growing demand for female labour, including migrant workers. Generally, operations performed by men are those that entail use of machinery and animals. Contrary to this, women always rely on manual labour using only their own energy. Not only are women overworked, their work is more arduous than that undertaken by men. Further, since women's work is largely based on human energy it is considered unskilled and hence less productive. On this basis, women are invariably paid less wage despite their working harder and for longer hours.
\end{abstract}

Copy Right, IJAR, 2018,. All rights reserved.

\section{Introduction:-}

Rural women perform numerous labour intensive jobs such as weeding, hoeing, grass cutting, picking, cotton stick collection, separation of seeds from fiber, keeping of livestock and its other associated activities like milking, milk processing, preparation of ghee, etc. They have to perform different activities in the home as well in the field throughout the day. They do not get any chance to take a nap and work like a machine without any break as compare with the man. Still women are considered as secondary workers in the economic scenario. The farm women perform almost each and every agricultural activity right from land preparation, weeding, sowing, transplanting to the harvesting and storage of the agricultural produce. The majority of these activities, which are full of drudgery, have not been supported by the mechanical advantages of tool and appliances. Moreover, most of the work-studies are directed towards the measurement of external forces and time spent in work. Occupational stress contributes not only to physical health but also impacts the psychological and mental health of the farm women. It also has a major impact on health of pregnant women farmers that include low birth weight of the fetus, deformity, etc. These contribute not only to life stresses, but has an impact on health and, thus, on the quality of farm life experienced by farmers. As globalization shifts from agriculture to capital intensive, women bear disproportionate costs of both displacement and health hazards. Occupational dust exposures have been associated with adverse pregnancy outcomes. It is not definite whether it is due to the preservatives such as pesticides or other agents like pentachlorophenol, creosote, formaldehyde, chromium, arsenic, etc. Maternal occupational pesticide exposure has also been identified as a risk factor for still birth. There were farm women in the study area that had a number of

Corresponding Author:-Smita Tripathi.

Address:-Post Doctoral Fellow, College of Home Science. 
abortions but had to work even after that without taking rest. Due to which they were suffering from severe backache and the need for bending constantly during transplanting operations was making their condition worse.

\section{Objectives:-}

1. To assess the occupational health hazards faced by women in performing various agricultural activities in the farm.

2. To analyze the occupational health problems of farm women.

\section{Methodology:-}

The study was conducted in Kanpur district of Uttar Pradesh which was purposively selected for the study purpose. One block, namely Kalyanpur was randomly selected from a total of ten blocks in the district. Random selection of 5 villages was done from the selected block from which a total sample size of 100 farm women of landless, marginal and small farmer category was drawn through systematic random sampling method to conduct the present investigation. Dependent and independent variables such as age, caste, education, income, health, role, knowledge, performance, etc. were studied. The statistical tools applied were percentage, mean score, rank, etc.

\section{Results:-}

Table 1:-Distribution of farm women according to age group

\begin{tabular}{|l|l|l|}
\hline Age group & Frequency & Per cent \\
\hline 20 to 30 years & 20 & 20.0 \\
\hline 30 to 40 years & 50 & 50.0 \\
\hline 40 to 50 years & 23 & 23.0 \\
\hline 50 years and above & 7 & 7.0 \\
\hline Total & 100 & 100.0 \\
\hline
\end{tabular}

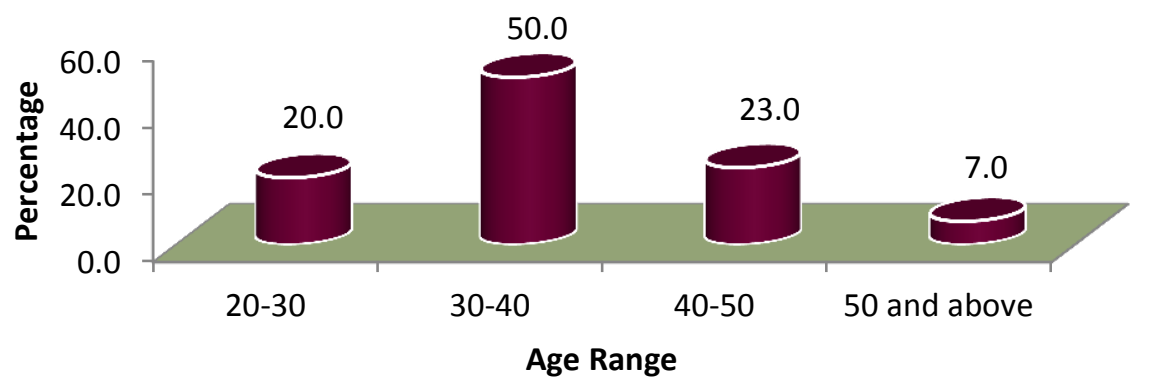

When women in rural areas have spent 10-12 years of their marriage and they are matured, they are accompanied by older women of the family and taken to the fields to contribute as a worker to their family's main occupation i.e. agriculture. So, it is clear that 50.0 per cent of the farm women working in the fields were of the age group 30 to 40 years, followed by women of the age 40 to 50 years.

Table 2:-Distribution of farm women according to land holding

\begin{tabular}{|l|l|l|}
\hline Category & Frequency & Per cent \\
\hline Landless & 25 & 25.0 \\
\hline Marginal & 55 & 55.0 \\
\hline Small & 20 & 20.0 \\
\hline Total & 100 & 100.0 \\
\hline
\end{tabular}




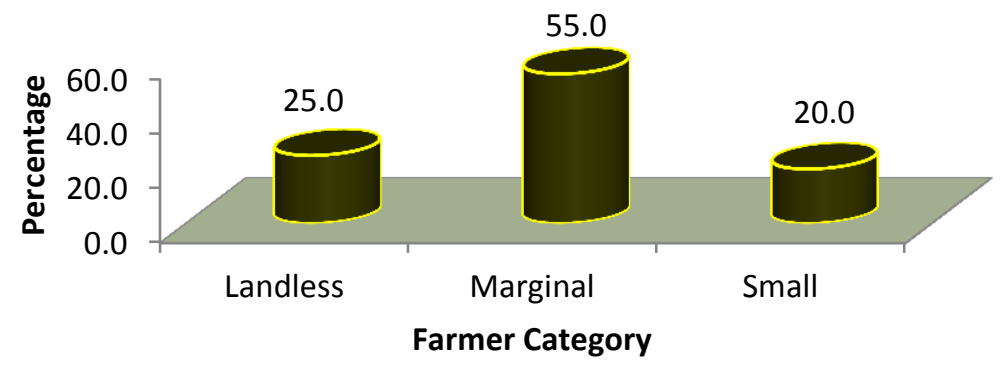

Marginal farmers had less cropping intensity, less level of adoption of modern agricultural technologies and less knowledge about hybrid seeds and inter-cropping system as compared to small farmers.

Table 3:-Participation and involvement of farm women in agricultural activities

\begin{tabular}{|l|l|l|l|l|}
\hline Agricultural activities & Monthly & No. of days & Time (hrs/days) & Posture \\
\hline Field preparation & 13 & 20 & 10 & Standing \\
\hline Seed selection & 2 & 10 & 5 & Sitting \\
\hline Seed treatment & 1 & 15 & 6 & Bending \\
\hline Weed control & 1.10 & 24 & 9 & Bending \\
\hline Weed management & 1.15 & 20 & 7 & Sitting \\
\hline Bunds making & 1.18 & 20 & 6 & Bending \\
\hline Puddling & 2 & 18 & 5 & Bending \\
\hline Uprooting \& transport of seedlings & 1 & 15 & 4 & Bending \\
\hline Transplanting & 2 & 15 & 10 & Bending \\
\hline Irrigation & 3 & 20 & 9 & Standing \\
\hline Fertilizer application & 2 & 10 & 6 & Standing \\
\hline Weeding & 3 & 20 & 8 & Sitting \\
\hline Insect pest control & 10 & 5 & Standing \\
\hline Harvesting & 1 & 18 & 10 & Sitting \\
\hline Bundle making & 4 & 22 & 8 & Bending \\
\hline Threshing & 2 & 24 & 8 & Standing \\
\hline Winnowing & 2 & 20 & 8 & Standing \\
\hline Storage & 1 & 22 & 8 & Bending \\
\hline Marketing & 2 & 25 & 7 & Sitting \\
\hline
\end{tabular}

Mainly rural women are engaged in agricultural activities in three different ways depending on the socio-economic status of their family and regional factors such as paid labourers, cultivator doing labour on their own land and managers of certain aspects of agricultural production by way of labour supervision and the participation in post harvest operations.
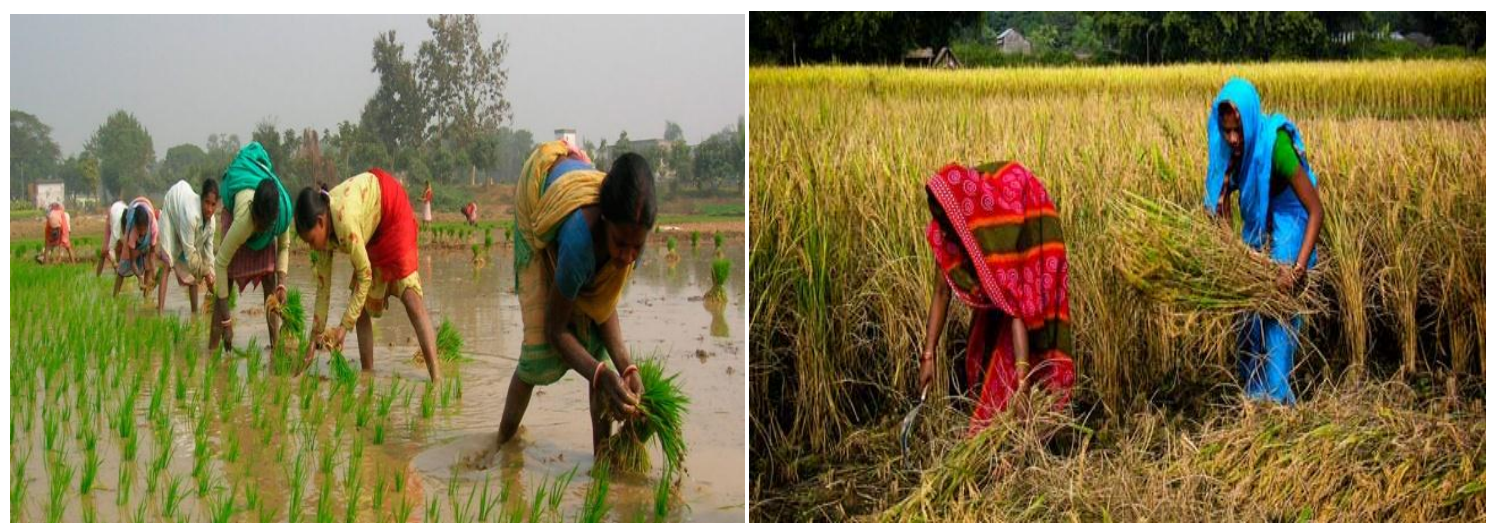
Table 4:-Distribution of farm women according to the types of health hazards faced by them while performing various agricultural activities

\begin{tabular}{|c|c|c|c|c|c|}
\hline \multirow[b]{2}{*}{ Activities } & \multirow[b]{2}{*}{ Health hazards } & \multicolumn{2}{|c|}{ Frequency } & \multirow{2}{*}{$\begin{array}{l}\text { Mean } \\
\text { score }\end{array}$} & \multirow[b]{2}{*}{ Rank } \\
\hline & & Yes & No & & \\
\hline \multirow[t]{7}{*}{ Irrigation } & - $\quad$ Headache & 90 & 10 & 1.90 & II \\
\hline & - Nausea/Vomiting & 70 & 30 & 1.70 & IV \\
\hline & - $\quad$ Fever & 76 & 24 & 1.76 & III \\
\hline & - $\quad$ Pneumonia & 47 & 53 & 1.47 & $\mathrm{~V}$ \\
\hline & - Weakness & 100 & - & 2.00 & $\mathrm{I}$ \\
\hline & - $\quad$ Body pain & 100 & - & 2.00 & I \\
\hline & - $\quad$ Accident/injuries & 35 & 65 & 1.35 & VI \\
\hline \multirow[t]{9}{*}{ Insect pest control } & - $\quad$ Suffocation & 55 & 45 & 1.55 & III \\
\hline & - $\quad$ Headache & 90 & 10 & 1.90 & $\mathrm{I}$ \\
\hline & - $\quad$ Nausea/vomiting & 35 & 65 & 1.35 & $\mathrm{~V}$ \\
\hline & - $\quad$ Allergies & 67 & 33 & 1.67 & II \\
\hline & - $\quad$ Asthma & 40 & 60 & 1.40 & IV \\
\hline & - $\quad$ Fetal death & 15 & 85 & 1.15 & VI \\
\hline & - $\quad$ Neuro development disorders & 5 & 95 & 1.85 & VII \\
\hline & - $\quad$ Birth defects & 15 & 85 & 1.15 & VI \\
\hline & - Urinary tract infection (UTI) & 15 & 85 & 1.15 & VI \\
\hline \multirow[t]{10}{*}{ Transplanting } & - $\quad$ Allergies & 65 & 35 & 1.65 & $\mathrm{~V}$ \\
\hline & - $\quad$ Insect biting & 70 & 30 & 1.70 & IV \\
\hline & - $\quad$ Hypersensitivity & 25 & 75 & 1.26 & IX \\
\hline & - Immuno deficiency & 15 & 85 & 1.15 & $\mathrm{X}$ \\
\hline & - Infection & 45 & 55 & 1.45 & VII \\
\hline & - $\quad$ Swollen hands and feet & 88 & 12 & 1.88 & I \\
\hline & - Eczema & 55 & 45 & 1.55 & VI \\
\hline & - $\quad$ Headache & 76 & 24 & 1.76 & III \\
\hline & - $\quad$ Nausea/Vomiting & 40 & 60 & 1.40 & VIII \\
\hline & - $\quad$ Body pain/Backache & 80 & 20 & 1.80 & II \\
\hline \multirow[t]{12}{*}{ Weeding } & - Tetanus & 25 & 75 & 1.25 & IX \\
\hline & - $\quad$ Pneumonia & 45 & 55 & 1.45 & VIII \\
\hline & - $\quad$ Body pain/Backache & 78 & 22 & 1.78 & $\mathrm{~V}$ \\
\hline & - Headache & 88 & 12 & 1.88 & I \\
\hline & - $\quad$ Nausea/Vomiting & 45 & 55 & 1.45 & VIII \\
\hline & - Heat exhaustion and heat stroke & 86 & 14 & 1.86 & II \\
\hline & - Skin allergies & 48 & 52 & 1.48 & VII \\
\hline & - Insect/Snake bite & 65 & 35 & 1.65 & VI \\
\hline & - $\quad$ Numbness and tingling in hand and feet & 82 & 18 & 1.82 & IV \\
\hline & - Problems caused by poisonous plants & 45 & 55 & 1.45 & VIII \\
\hline & - $\quad$ Fatigue & 85 & 15 & 1.85 & III \\
\hline & - $\quad$ Flu & 10 & 90 & 1.10 & $\mathrm{X}$ \\
\hline \multirow{8}{*}{$\begin{array}{l}\text { Harvesting, threshing } \\
\text { and winnowing }\end{array}$} & - Headache & 76 & 24 & 1.76 & IV \\
\hline & - $\quad$ Asthma & 25 & 75 & 1.25 & VIII \\
\hline & - $\quad$ Accidents/injuries & 68 & 32 & 1.68 & $\mathrm{~V}$ \\
\hline & - $\quad$ Suffocation & 62 & 48 & 1.52 & VI \\
\hline & - $\quad$ Irritation in eyes, nose, throat & 88 & 12 & 1.88 & $\mathrm{I}$ \\
\hline & - Bronchitis & 35 & 65 & 1.35 & VII \\
\hline & - $\quad$ Body pain with fever & 72 & 28 & 1.72 & III \\
\hline & - $\quad$ Backache & 80 & 20 & 1.80 & II \\
\hline
\end{tabular}




\begin{tabular}{|l|l|l|l|l|l|}
\hline $\begin{array}{c}\text { Transportation and } \\
\text { marketing of farm } \\
\text { produce }\end{array}$ & $\bullet$ Accidents/injuries & 45 & 55 & 1.45 & V \\
\hline & $\bullet$ Headache & 65 & 35 & 1.65 & IV \\
\hline & $\bullet$ Backache & 79 & 21 & 1.79 & II \\
\hline & $\bullet$ Body pain & 83 & 17 & 1.83 & I \\
\hline & $\bullet$ Muscle pull & 70 & 30 & 1.70 & III \\
\hline & $\bullet$ Miscarriage/abortion/ bleeding & 10 & 90 & 1.10 & VI \\
\hline
\end{tabular}

There are many pesticides farm women are heavily exposed to that are known to damage the brain and nervous system, or cause cancer, or birth defects. Many of the respondents said that they do not even know the names or hazards of the pesticides they are mixing and applying. They receive no education or training in how to use them properly or how to protect themselves and their children. They have no water to wash off the pesticides or to drink. Eventually they suffer from watery eyes, nausea, nose bleeds, discoloured fingernails, etc.

Table 5:-Distribution of farm women according to the causes of accidents during agricultural operations

\begin{tabular}{|c|c|c|c|c|}
\hline \multirow[t]{2}{*}{ Causes } & \multicolumn{2}{|c|}{ Frequency } & \multirow{2}{*}{$\begin{array}{l}\text { Mean } \\
\text { score }\end{array}$} & \multirow[b]{2}{*}{ Rank } \\
\hline & Yes & No & & \\
\hline Wearing loose clothes & 85 & 15 & 1.85 & II \\
\hline Not maintaining proper distance from moving machines & 25 & 75 & 1.25 & $\mathrm{~V}$ \\
\hline Poor driving & - & 100 & 1.00 & VIII \\
\hline Poor tractor stability & - & 100 & 1.00 & VIII \\
\hline Contact with sharp objects & 62 & 38 & 1.62 & III \\
\hline Over exertion & 90 & 10 & 1.90 & $\mathrm{I}$ \\
\hline Falling/disbalancing & 45 & 55 & 1.45 & IV \\
\hline Struck by falling objects & 5 & 85 & 1.05 & VII \\
\hline Open power transmission & 15 & 85 & 1.15 & VI \\
\hline
\end{tabular}

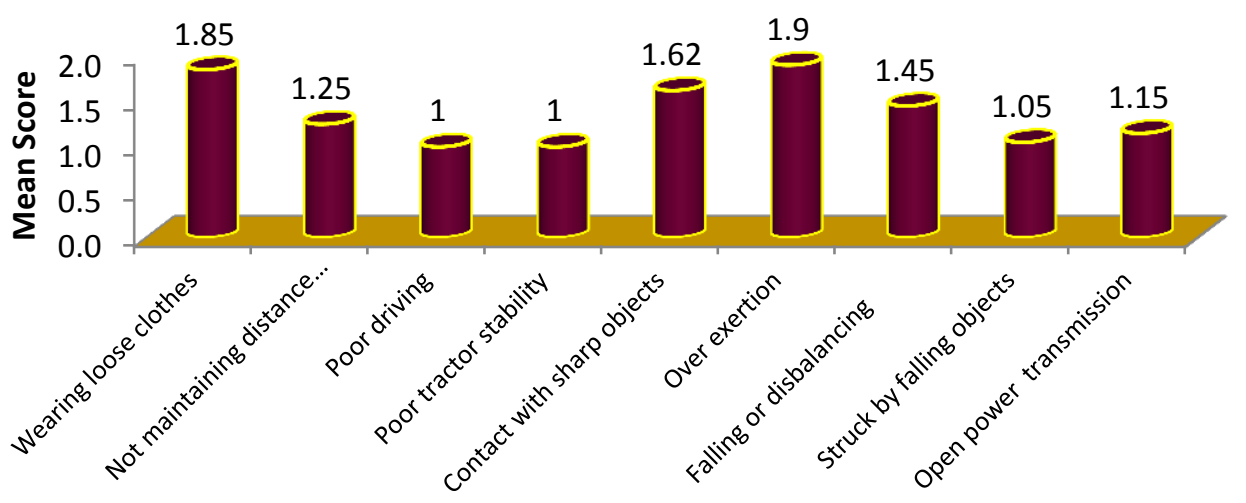

Causes

Accidents happen more among farm women during farm activities when they are devoid of knowledge, awareness and ignorant about the use of chemicals and farm tools and equipments. Sharp tools and farm equipment injuries ranging from cuts to fatalities, hearing impairment from loud machinery are common in rural areas where people are ignorant towards taking basic precautionary measures. Most farm situations require a wide variety of skill levels for which farm women have little formal training and there are few hazard controls on tools and equipment.

\section{Conclusion:-}

A number of factors predispose farm women to various health hazards, such as age, sex, race, temperature and humidity, working conditions, hours of working, previous body or skin disorders, personal hygiene, etc. Health and injuries also depend on the type of farming activity, the type of worker and the geographic location. Basic hazards such as sharp tools and snake bites can also cause debilitating wounds and fatalities. Work related skin diseases are 
often easy to detect, but difficult to diagnose. Wearing proper protective clothing and washing frequently are the most effective means of prevention. Skin cancer is a concern on the farm due to the long hours farmers spend in the sun. Skin cancer is the most common form of cancer with about 39.6 per cent diagnosed cases of all cancers in India each year. Ninety per cent of all skin cancers occur on parts of the body not usually covered by clothing. A place of particular concern for farmers is the back of the neck. Farm women should avoid overexposure, especially between 11 a.m. and 2 p.m., use sun blocks that absorb or deflect ultraviolet rays, wear protective clothing, such as longsleeved shirts, pants and wide brimmed hats and conduct regular self-examinations for early detection. Farm women often suffer from itching, burning, swollen and sore hands and feet, as well as allergies, fetal death, birth defect, watering eyes after spraying pesticides or working in freshly sprayed fields. Some pesticides are more toxic than others. Misuse of such pesticides can cause illness or even death. Simple first-aid measures, if applied at night time, can help to save many lives.

If farm women have to perform hi-tech farm operations and use modern farm technologies, then it is essential to provide them with compete knowledge about the use and functioning of equipments, proper handling of tools and chemicals, importance of work rest schedule and also make them cautious about the precautionary measures they should take while working on fields such as careful use of sharp objects, proper distance from moving machines and importance of wearing appropriate clothing.

\section{Recommendations:-}

1. As women have different ergonomical characteristics than men, it is essential to initiate women oriented researches in agriculture and design women friendly tools and equipments to derive solutions that minimize the damage caused to health and loss of production. This will minimize the health problems of farm women and improve their status, productivity and profitability, thus, adding to the country's overall economic growth.

2. Setting objectives and targets to eliminate/ control/minimize the risks due to occupational and safety hazards.

3. Establish safety standards with regard to the design, manufacture and use of tractors and other machinery used in agriculture, based on sound scientific criteria and accepted international practice.

4. Using appropriate protective measures such as hand gloves, face masks, apron, booths, etc. when working with or using chemicals.

5. Rest breaks between works are necessary for the labours.

6. The department of agriculture should train women in handling of agricultural implements.

7. Extension workers should transfer the new technologies released with regular training and awareness programme for women.

8. Use of "environment-friendly" labels and logos, massive advertisements on TV and radio, sponsoring of cultural and school programmes in rural areas etc.

\section{References:-}

1. Ackerson, Nana O.B. and Awuah, Esi (2013): "Urban Agriculture Practices and Health Problems among Farmers Operating on a University Campus in Kumasi, Ghana".The Journal of Field Action, Field Action Sciences Report. Special Issue 1

2. Amodu M.F. Bimba, J.S. and Bolori, M.T. (2017): "Assessment of occupational hazards and health problems among female farmers in north-eastern Nigeria”. Arid Zone Journal of Engineering, Technology and Environment. 13(2):209-218.

3. Department of Health and Human Services, State Government of Victoria, Australia (2018): Better Health Channel. https://www.betterhealth.vic.gov. au/ health/healthyliving/farm-safety-machinery.

4. Kazantzis George (2018): “Occupational disease". Encyclopedia Britannica. pp-1-2. https://www.britannica.com/science/occupational-disease

5. Rural health information hub (2017): "Rural Agricultural Health and Safety". https://www.ruralhealthinfo.org. 